\title{
Implementation of Internal Quality Guarantee System to Increase the Quality of Education in Junior High School 21 Malang
}

\author{
Ika Rahmania ${ }^{1}$, Budiono ${ }^{2}$, Siti Fatimah Soenaryo ${ }^{2}$, Abd. Syakur ${ }^{2}$, Agus Tinus ${ }^{2}$ \\ ${ }^{I}$ Master Student in Education Policy and Development, Universitas Muhammadiyah Malang, Indonesia \\ ${ }^{2}$ Lecturer in Education Policy and Development, Universitas Muhammadiyah Malang, Indonesia \\ i3_ka@yahoo.co.id,budiono_fkipumm@yahoo.co.id,syakurabdmpd@gmail.com,agt_tns@yahoo.com
}

\section{Abstract}

The purpose of this study is to examine the implementation of SPMI, examine the results of the implementation of SPMI and examine the factors inhibiting the implementation of SPMI in Junior High School 21 Malang as an effort to improve the quality of education. Primary data were obtained from the SPMI implementers, namely the school principal, supervisors and the quality assurance team at Junior High School 21 Malang. Secondary data were obtained from references, books and documents related to the implementation of SPMI. Data analysis techniques used in this study consisted of three stages, namely data reduction, data presentation and conclusion drawing. The results of this study indicate that the implementation of SPMI in Junior High School 21 Malang is documented from 2016 to 2019. The implementation of SPMI involves all components of the school from top to bottom. The implementation of SPMI begins with quality mapping, quality fulfillment planning, implementation of quality fulfillment, evaluation and standard setting is proceeding well. The successful implementation of SPMI has increased as evidenced by graduates in 2019 getting 4th place on the results of the Computer-Based National Examination (UNBK). Implementation of quality has become a culture and character that influences the quality of graduates of Junior High School 21 Malang.

\section{Keywords}

IQAS implementation; internal quality assurance system; education quality

\section{Introduction}

The education system in Indonesia consists of three types, namely: informal education, non-formal education, and formal education. Informal education is education that is held in the family. Non-formal education is education that is organized by certain institutions such as courses. Usually, this education is vocational, short-term, and focused on. One particular bed. Meanwhile, formal education is school education, which is systematic, structured and tiered (Simarmata, 2015). One of the efforts to improve the quality of education is improving the quality of human resources. Education is a conscious effort for someone to change themselves better, by following the learning process that is expected to shape one's character, knowledge and physical fitness (Rohmana, 2019). The government realizes that education, especially formal education, is a big investment, in developing the nation. Therefore, education needs quality. It is also realized that a quality nation is very dependent on the quality of its education. In other words, the quality of a nation is determined by the high and low quality of the nation's education.

The definition of quality can be seen from two sides, namely the producer side and the consumer side. From the producer side, as mentioned by Philip B. Crossby in Hadith (2014), a product is said to be of good quality if the product is in accordance with the standard. In this 
case, the standard is set by the manufacturer. In the world of education, the producers are the government and education unit providers. The government has set eight national education standards, namely: 1) standard content, 2) standard process, 3) graduate competency standards, 4) educator and educational staff standards, 5) management standards, 6) standard. financing, 7) standard of facilities and infrastructure, and 8) assessment standards. On the consumer side, as stated by Edward Deming and Feiguenbaun in Hadith (2014), Deming said that quality products are products that can meet consumer needs. Feiguenbaun said that quality products are products that can satisfy customers. In the world of education, the customers or consumers are students and their parents.

Quality in education is an evaluation of the educational process that increases the need to achieve and the process of developing the talents of customers (students), and at the same time meet the accountability standards set by the client (stakeholders) who pay for the process or output of the educational process. (Fadhli , 2017). Quality (Quality) education is not something that happens by itself, it is the result of an educational process, if an education process runs well, effectively and efficiently, then there is a huge opportunity to obtain quality educational outcomes. (Munjin, 2013)

According to Dhartamuda (2015), descriptive quality is the success of student learning outcomes tests that meet the ideal standards of education. Meanwhile according to Fattah (2012), measurement of achievement of reference standards and evaluation of education quality is carried out on educational units / programs through: self-evaluation of education units, monitoring by local governments, accreditation, certification, national examinations and data collection and database data. Measuring the achievement of educational quality reference standards related to the achievement of Graduates Competency Standards. The measurement will produce a student graduation rate nationally. The data obtained in this measurement are the students' performance and achievement data.

Each education provider and unit requires a basic reference for realizing national education, which includes criteria for various aspects related to the delivery of education. The basic reference is an education standard to improve the performance of education providers so that transparency and public accountability are realized. Education standards are expected to be able to spur educational unit organizers or managers to improve quality education services. (Barnawi, 2017).

National education standard (SNP) is the minimum standard set by the government in the field of education that must be met by the education unit and all stakeholders in managing and organizing education, which consists of: 1) Competency Standards for Graduates; 2) Content Standards; 3) Process Standards, 4) Assessment Standards, 5) Educators and Teaching Staff Standards, 6) Management Standards; 7) Facilities and Infrastructure Standards; and 8) Financing Standards. According to Sani, et al (2018), the main reference for the quality assurance system for primary and secondary education is the National Education Standards (SNP) established by the central government through the National Education Standards Agency (BSNP).

Quality report cards from the results of the Education Quality Mapping (PMP) help to identify problems, program evaluations and target achievement. Schools can identify their own strengths and weaknesses and plan for future development. Strengthen the culture of institutional evaluation and self-analysis. Encourage schools to review policies that are outdated. Provides information about the status of the school compared to other schools. Schools can have accurate basic data as a basis for future development and improvement 
Schools can identify opportunities and challenges to improve the quality of education (Rudi, 2019)

In an effort to improve the quality of education, the government through the Ministry of Education and Culture issued a policy on education quality assurance. Education quality assurance efforts by the government are then implemented into the Education Quality Assurance System (SPMP). In accordance with the Ministry of Education and Culture Regulation No. 28 of 2016, it is stated that Education Quality Assurance is a systematic, integrated and sustainable mechanism to ensure that the entire educational implementation process is in accordance with quality standards. Another understanding, quality assurance is an activity to provide evidence as an effort to build trust that quality can run effectively (Effendi, 2017).

\section{Research Methods}

This type of research used in this research is descriptive qualitative research that is an analysis that describes the state or status of a phenomenon with words or sentences, then separated according to categories to obtain conclusions. This study aims to describe empirical reality according to the phenomenon in detail and thoroughly, and to express symptoms holistically contextual through collecting data from a natural setting by utilizing the researchers themselves as a key instrument (Sugiyono, 2015).

In accordance with the title, this research was conducted at Junior High School 21 Malang, located on Jl. Danau Tigi, Lesanpuro, Kedungkandang, Malang City. The study was conducted in January 2019 until August 2019. Researchers chose the place because there is one school in the city of Malang that has many academic and non-academic achievements. In addition, this school is also an impact school of a model school to implement the Internal Quality Assurance System. In the implementation process, the impact schools use their own funds without assistance from LPMP.

\section{Result and Discussion}

\section{Results}

The results of research on the implementation of the internal quality assurance system to improve the quality of education in Junior High School 21 Malang are as follows: 1) What is the implementation of the Internal Quality Assurance System program in an effort to improve the quality of education at Junior High School 21 Malang ?; 2) What is the result of the Internal Quality Assurance system in an effort to improve the quality of education in Junior High School 21 Malang ?; 3) What are the inhibiting factors and solutions to problems in the implementation of the Internal Quality Assurance System program in Junior High School 21 Malang?

\subsection{Implementation of the Internal Quality Assurance System Program in an Effort to Improve the Quality of Education in Junior High School 21 Malang}

Junior High School 21 Malang has implemented an internal quality assurance system since 2016 by becoming an impact school of SMP Negeri 22 Malang. Over time in 2019 Malang Public Middle School 21 was appointed to be a model school. The implementation of this internal quality assurance system cannot be separated from the participation of all components of the education unit so that it can produce graduates who are cultured in quality. 
This statement was confirmed8 with the results of interviews conducted by researchers with the Principal who said that:

We have implemented the internal quality assurance system since the beginning of the internal quality assurance system, which is in 2016 until now. We implement an internal quality assurance system by involving all components of the school, because without the cooperation of all parties the quality culture that is in accordance with the SNP is impossible to achieve. So in the beginning when our school was appointed to be an impact school, the first thing we did was to form a school quality assurance team to implement an internal quality assurance system in accordance with its cycle, namely quality mapping, quality fulfillment planning, implementation of quality fulfillment, evaluation and standard setting. We also conduct socialization in the form of workshops to all teachers and education personnel related to the internal quality assurance system in order to understand how the process is. (KS / 07/08/2019).

Based on the explanation of the interview above what was done by the researcher to the principal, that the school had already implemented an internal quality assurance system to improve the quality of the education in the school. School efforts in the implementation of the internal quality assurance system are carried out following the stages, namely quality mapping, quality fulfillment planning, implementation of quality fulfillment, evaluation or quality audits and setting standards. This statement is reinforced by the response of the teacher who acts as the head of the school quality assurance team interviewed by the researcher. The teacher said that:

The school has implemented an internal quality assurance system since becoming an impact school until now it has become a model school. All school components are involved in this internal quality assurance system, ranging from school supervisors, school principals, school committees, teachers and administrative staff. We all work with the team so that later we can improve the quality of the school. Because as we all know the quality of schools can be measured from the 8 components of SNP, graduates' competency standards, management standards, process standards, content standards, assessment standards, teacher and education personnel standards and financing standards, each of which components of the standard are interconnected with each other, so it cannot be done by individuals alone. We carry out an internal quality assurance system in accordance with regulations, starting from quality mapping, quality fulfillment planning, implementing quality compliance, evaluating or auditing quality and setting standards. (KTPMS / 07/08/2019).

Further related to the implementation of the internal quality assurance system explained by the person in charge of graduate competency standards such as the following interview results:

The quality mapping process is obtained from the quality report card, then the quality report is analyzed according to the competency standard whose value is still lacking, after which a quality fulfillment planning is carried out. The quality fulfillment plan also looks at the priority of the program because it is related to the vision and mission and goals of the school, besides the urgency of resolving the problem immediately so that it does not have a negative impact on other conditions. The next step is the fulfillment of quality based on quality fulfillment planning documents that must be carried out by all parties involved in it. And the last step is evaluating quality fulfillment to see the level of success of the program and 
recommendations for the preparation of further programs so that later it can improve school quality. (PSKL / 07/08/2019).

Based on the results of the study the documents and observations made by researchers related to the implementation of the internal quality assurance system (SPMI) in an effort to improve the quality of education in Junior High School 21 Malang is good, the implementation is in accordance with the cycle set by the government and worked with the team This is evidenced by some information from some information through interviews with researchers and some supporting documents such as quality report cards that have increased performance from 2016 to 2018, SK school quality assurance team decree and SPMI documents which include quality mapping analysis documents, quality fulfillment plan documents, quality fulfillment implementation documents and evaluation of quality fulfillment implementation documents as benchmarks for the future.

\subsection{Results of the Implementation of the Internal Quality Assurance System in an Effort to Improve the Quality of Education in Junior High School 21 Malang}

The implementation of the internal quality assurance system has a good impact on efforts to improve the quality of education in Junior High School 21 Malang. This is evident from the results of the average UNBK score for the 2018/2019 school year, which ranks 4th in state schools in Malang. The average results of UNBK also increased compared to the $2017 / 2018$ school year.

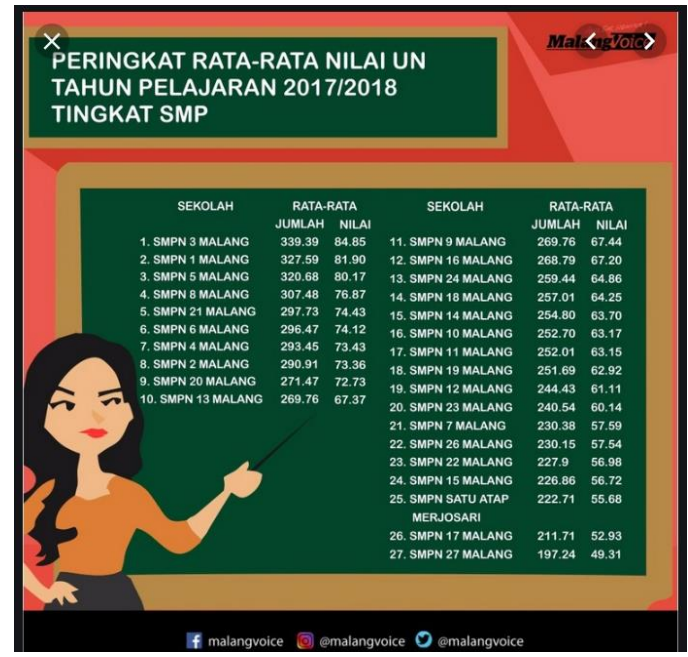

Figure 1. The average results of UNBK in the top 10 SMP in Malang in the academic year $2017 / 2018$

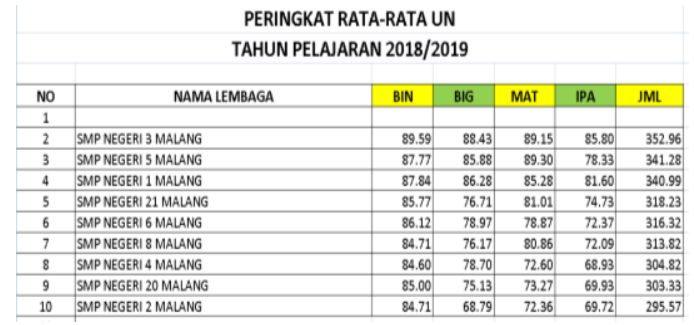

Figure 2. The average results of the 10 major UNBK SMP in Malang in 2018/2019 
In the picture above, both graduates of 2017/2018 and graduates of 2018/2019 show that graduates of Junior High School 21 Malang have experienced an increase in their academic fields. This, according to the interview conducted by the researcher to the principal, which states that:

With this internal quality assurance system, judging from the results of the graduates this year our school ranked 4th in the state junior high school in Malang and also one of our students, the UNBK result ranked 1st in the SMP in Malang. All of these achievements are inseparable from the support and participation of all school residents. (KS / 07/08/2019).

The statement was reinforced by the head of the school quality assurance team, which stated that:

Every Tuesday, Wednesday and Thursday at $06.00 \mathrm{WIB}$, grade 9 students attend tutoring. Student guardians greatly appreciate this program. Likewise, the teachers are willing to come in the morning to give additional lessons to the children. Without the support of all parties, it is not possible for Junior High School 21 Malang to succeed in achieving 4th place in the UNBK results and for being ranked 1 in the UNBK results. (KTPMS / 07/08/2019).

Besides looking at the value of graduate results, the results of this internal quality assurance system also have an impact on the quality culture of students. This can be seen from the habituation program implemented in Junior High School 21 Malang, as stated by the curriculum waka who is also included in the school quality assurance team as follows:

Every morning there is an Imtaq coaching activity then followed by an insight into the nationality of patriotism and literacy activities. Activity is followed by all students, held in the morning at 06:45 to 07:15 on the school page. The children came straight to the backyard and immediately sat on their respective pedestals. Then guided by students who have been appointed to read short letters and Asmaul Husna, then proceed to sing the national anthem and finally literacy activities where children bring their own books. The existence of this literacy activity is expected to encourage children to have lifelong learner behavior in accordance with the results of our quality mapping analysis. (WK/ 07/08/2019).

The internal quality assurance system has been implemented in Junior High School 21 Malang, but the results from the 2018 quality report card have decreased when compared to 2017.

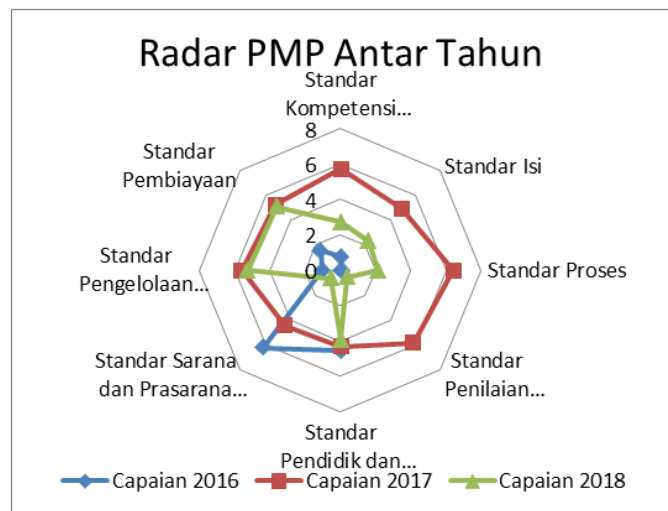

Figure 2. Education Quality Assurance Radar Results for 2018 
From the results of the radar education quality assurance achievements for 2018 experienced a significant decline. Based on the results of an interview with one of the school education quality assurance teams stated that:

The results of education quality assurance have decreased in 2018, the cause is due to constraints on uploading data and when the server filling process in LPMP is down, so there are some data that cannot be uploaded properly and causes many indicators on the quality report card to be red. However, after being validated by the school education quality assurance team, we can map which ones should meet the requirements and which ones have not. The results of the validation of many grades from the quality report cards are not in accordance with the conditions at school. (TPMPS / 07/01/2020)

\subsection{Inhibiting Factors and Solutions to Problems in Implementing the Internal Quality Assurance System Program in Junior High School 21 Malang}

The process of implementing the internal quality assurance system (SPMI) in Junior High School 21 Malang did not run smoothly, but there were still factors that became obstacles in order to achieve a quality culture school. Some of these factors greatly affect the implementation of SPMI in improving the quality of education. This inhibiting factor also affects the quality report card results. This is reinforced by the statement of the Principal, stating that:

Indeed there are several obstacles or factors faced in improving the quality of education in this school, such as the unavailability of librarians and laboratory assistants in accordance with the provisions which ultimately impact on the quality fulfillment process that cannot run properly because librarians and laboratory staff are held by teachers who are not an expert. However, we are trying for librarians, even though they are taken from teachers whose teaching duties are in fact, we reduce the teacher's learning hours to 12 hours and for the head of the library in dapodik recognized 12 hours, so that the teacher still fulfills 24 hours of teaching, so that the teacher can carrying out tasks in the library with the help of administrative staff. As for actual laboratory staff, schools want to look for experts in their fields, but are constrained by funding during the process of quality fulfillment, because there are 3 laboratory assistants needed by the school, namely science laboratory assistants, language laboratory assistants, and computer assistant staff. Like computer technicians we only call upon approaching computer-based exams. (KS / 07/08/2019).

Several factors were explained by the school principal. Indeed they were factors that generally influenced the results of school quality report cards. In addition, there are still several factors obstacles that affect the implementation of the internal quality assurance system such as the lack of supporting facilities in the process of improving school quality. This is reinforced by the statement of one of the school quality assurance teams, which states that:

Perhaps one of the factors that hindered the implementation of SPMI is one of them because of our lack of understanding to adjust quality planning with school work plans. It is also related to funding, because schools get funds only from School Operational Assistance (BOS). We all know that the preparation of the BOS RKA is done 1 year before its implementation, so that during the planning process the quality fulfillment must also be adjusted to the RKA that has been made. In addition, the availability of availability of facilities and infrastructure in schools is also still not in 
accordance with the provisions, for example, the number of bathrooms that are not in accordance with the capacity of the number of students. (TPMS / 07/08/2019).

The same thing was stated by one of the school quality assurance teams in this study, which stated that:

Not all school programs are funded by BOS, for example tutoring is given to grade 9 students. Tutoring is one of the school programs to improve the quality of grade 9 students, so that later students get the best value for their knowledge. Because the tuition fees are not covered in the RKA, the role of the committee is needed for the smooth running of the program. (TPMS / 07/08/2019).

In addition to the above factors, there are also factors that hinder the implementation of SPMI, which is during the quality mapping process. This is consistent with the results of interviews conducted by researchers with the head of the school quality assurance team, who stated that:

Quality mapping is done online by filling out a quality mapping instrument application. The filling is carried out by the school principal, supervisor supervisors, teachers, students in grades 7, 8 and 9, as well as the school committee. Because the number of questions in the questionnaire is large, and often the internet connection is not smooth, so at the time of filling it sometimes feels bored and finally answers perfunctory, not in accordance with the reality on the ground. Though ideally filling instruments is done correctly not just filling out forms, resulting in poor quality report cards and not in accordance with the real conditions at school. For this reason, this year the dapodik operator is filling in the instrument for improving the quality of education, but previously the list of questions was filled out by each person who had been appointed. The hope is not to interfere with assignments and answers according to conditions at school. (KTPMS / 07/08/2019).

\section{Discussion}

Based on the results observation of the data analysis that has been presented in the research results. So, researchers describe the data based on relevant theories. This research focuses on "the implementation of an internal quality assurance system to improve the quality of education in Junior High School 21 Malang". Then the researcher elaborates through subsections in the formulation of the problem.

\subsection{Implementation of the Internal Quality Assurance System Program in an Effort to Improve the Quality of Education in Junior High School 21 Malang}

In the world of education, educators must not produce graduates who are not good. One of the efforts made by the government to improve the quality of graduates is to require education units to carry out education quality assurance. Quality assurance of education is carried out with the aim that education units can meet national education standards (SNP). Without the implementation of education quality assurance, the effectiveness of improving education quality is unknown. Therefore, quality assurance must be carried out from the beginning of the education process.

The implementation of SPMI in Junior High School 21 Malang following the yarng procedure is in the guideline of the quality assurance system for primary and secondary education. It starts with the school principal's socialization to the school community through workshops with SPMI presenters conducted by the school supervisor as a regional facilitator appointed by LPMP. Then the school principal forms a school quality assurance team 
(TPMS). TPMS consists of the principal as the person in charge, the teacher, the school committee and administrative staff. The principal made a TPMS decision letter along with a description of the division of tasks and guidelines for the implementation of the internal quality assurance system (SPMI). The SPMI stages consist of 5 stages, namely: 1) quality mapping; 2) preparation of quality fulfillment plans; 3) implementation of quality fulfillment; 4) quality fulfillment evaluation and audit; and 5) quality standard setting. (Asia, 2017).

According to Sani, et al (2018), evaluation of quality fulfillment is a systematic and independent testing phase to determine whether the implementation and results of quality fulfillment are in accordance with the planned strategy and whether the strategy is implemented effectively and is appropriate to achieve the objectives. At Junior High School 21 Malang an internal evaluation and audit team was formed. They are tasked with preparing the monitoring and evaluation instruments for the process of implementing quality fulfillment and providing recommendations for quality fulfillment strategies based on the results of monitoring and evaluation of the entire school quality assurance team so that later there is a guarantee of certainty of ongoing quality improvement.

The implementation of the internal quality assurance system at Junior High School 21 Malang in general has proceeded in accordance with the cycle set by the government. Schools that can already run SPMI can improve the quality of these schools. Because basically something is said to be of good quality if it reaches the specified specifications (Sallis, 2011). According to Puspitasari (2017), the internal quality assurance system makes schools the main actors or the spearhead of education quality assurance. The quality of education is no longer the responsibility of certain parties, but rather the responsibility of all school residents.

\subsection{Results of the Internal Quality Assurance System in an Effort to Improve the Quality of Education in Junior High School 21 Malang}

The results obtained from the implementation of this quality assurance system can be seen from the academic scores of graduates who get an average score of the 4 th national exam in Malang, also getting 1st place in the UNBK in Malang. Good characters are also shared by students because every day habituation activities are carried out, both Imtaq habituation, homeland love, literacy and environmental love. Everything is inseparable from the participation of all school residents who have carried out quality assurance so that later graduates from Junior High School 21 Malang have graduates who have quality culture. Schools with quality culture will be able to fulfill the SNP, so that in the education unit will be found enjoyable learning. The impact of such a learning process is the production of graduates who have good character, are creative, and are lifelong learners. (Sani, et al, 2018).

\subsection{Inhibiting Factors and Solutions to Problems in Implementing the Internal Quality} Assurance System Program in Junior High School 21 Malang

Not a few educational institutions that implement the SPMI quality assurance system, do not get the expected results. The quality assurance program has been implemented, the equipment has been prepared, the documents have been built, millions of rupiah investment has been issued, but the expected quality improvements cannot be felt and there are no significant changes, even tragically all implementers have become apathetic.

Planning programs that require no cost can be an alternative solution in dealing with limitations ... financial management owned by educational institutions such as schools. The preparation of the RKA is done at the beginning of the year, while the school self-evaluation 
and quality fulfillment planning are carried out during the middle of the year. This results in difficult to achieve good quality education. Therefore the school needs to hold the community to be involved in the success of the school program in accordance with applicable regulations. The financing policy established by the government is the basis for raising awareness and exploring sources of funds by building cooperation between the government and the community. The stipulated financing policy is the basis for supporting the achievement of graduate competency standards; foster public awareness about the importance of education; improve the competence of educators and education staff; education services; and explore sources of funds by building cooperation between the government and the community. (Kurniady, 2011).

Facilities and infrastructure factors that affect the results of the quality report are the internet network. At the time of sending data online, it cannot be done in a hurry, it must be carefully considered in filling out the data. In addition, school facilities and infrastructure factors such as the limited number of student bathrooms is very influential in improving the quality of schools. The ratio of the number of students to the number of student bathrooms is not balanced. This limitation has an effect on the implementation of school programs. For this reason, schools are trying to submit funds to the government. Schools must be able to develop various financing strategies in order to achieve school goals and the quality of education. The importance of planning school financing strategies in improving quality needs to be known, realized, and reviewed by related parties so that it brings positive changes to the sustainability and achievement of school goals. (Tius, Margareta \& Ismanto, 2017).

\section{Conclusion}

First, that the internal quality assurance system at Junior High School 21 Malang has been implemented, the appointment of Junior High School 21 Malang as an impact school and then subsequently being designated as a model school is a form of internal quality assurance systems at schools. Quality mapping, quality planning, quality evaluation or auditing and standard setting are carried out as benchmarks for internal quality assurance systems in schools.

Second, that the results of the internal quality assurance system conducted at Junior High School 21 Malang get a positive form of results marked by the quality of graduates in the cognitive domain that is getting better as evidenced by the results of graduates who ranked 4th on the average UNBK exam results. Quality culture in students has also been seen through habituation programs such as imtaq, national insights and literacy activities conducted in the morning and followed by all students. In addition, in learning activities all teachers carry out attitude assessments to control children's behavior. Furthermore, the results of the education quality assurance report card in Junior High School 21 Malang, although many are below the SNP achievement and tend to go down from the previous year, but the results of the validation show a discrepancy with the actual conditions at school.

Third, that there are several factors that become obstacles and solutions in implementing the internal quality assurance system in Junior High School 21 Malang among these factors and solutions is the absence of library staff and laboratory assistants in accordance with the provisions so that both of these staff are held by the teacher. Then other factors are funding problems during the process of quality fulfillment, facilities in the process of improving quality. Not all funds are financed by the schools which only get funds from the School Operational Assistance (BOS), so schools are trying to find funding from the 
government or from parties the outside. In addition, the process of filling quality instruments is also one of the inhibiting factors because it is done online and sometimes technically there is network interference so that the process of filling instruments is disrupted which results in quality report cards not matching the conditions at school, for that the school tries as much as possible at when charging the instrument by charging at the beginning, and looking for a loose time so that when charging can focus.

\section{References}

Asia. (2017). Implementasi Sistem Penjaminan Mutu Internal Sebagai Upaya Meningkatkan Mutu Pendidikan Di SMP Negeri 3 Palu, 1-11.

Barnawi dan Arifin, M. (2017). Sistem Penjaminan Mutu Pendidikan. Yogyakarta : Arruz Media.

Dhartamuda, S. A. (2015). Manajemen Peningkatan Mutu Berbasis Sekolah (Studi Kasus Pada Yayasan Bahana Cita Persada Kota Malang). Universitas Islam Negeri Maulana Malik Ibrahim Malang.

Effendi, Alwan. (2017). Manajemen Mutu Pendidikan. Yogyakarta : Media Akademi.

Fadhli, M. (2017). Manajemen Peningkatan Mutu Pendidikan. Studi Manajemen Pendidikan, $1(02)$.

Fattah, Nanang. (2017). Sistem Penjaminan Mutu Pendidikan. Bandung: Remaja Rosdakarya. Hadis, Abdul \& Nurhayati. (2014). Manajemen Mutu Pendidikan. Bandung: Alfabeta.

Kemdikbud. (2016). Pedoman Umum Sistem Penjaminan Mutu Pendidikan Dasar dan Menengah. Jakarta.

Kemdikbud. (2017). Petunjuk Pelaksanaan Penjaminan Mutu Pendidikan Oleh Satuan Pendidikan. Jakarta.

Kurniady, D. A. (2011). pengelolaan pembiayaan sekolah dasar di kabupaten bandung. Penelitian Pendidikan, 12(1), 34-51.

Lubis, A. N. S. dan W. (2017). Manajemen pendidik dan tenaga kependidikan dalam meningkatkan mutu pendidikan. EducanduM, X, 1-12.

Mariana, I. M. A. (2013). Anatomi Sistem Penjaminan Mutu Pendidikan. Denpasar.

Munjin. (2013). Sistem Penjaminan Mutu Pendidikan Di Madrasah. Dakwah \& Komunikasi, $7(2)$.

Nuryahya, E. M. (2018). Manajemen Penjaminan Mutu Internal Tenaga Pendidik dan Kependidikan (Studi Kasus Di Sekolah Menengah Pertama (SMP) Al Hikmah Surabaya).

Olufunke, I., \& Joseph, S. (2012). Quality Assurance and Effectiveness of Lagos State Junior Secondary Schools. International Journal of Humanites and Social Science, 2(15), 166170.

Puspitasari, H. (2017). Standar Proses Pembelajaran Sebagai Sistem Penjaminan Mutu Internal Di Sekolah. Muslim Heritage, 1, 339-368.

Sallis, E. (2011). Total Quality Management In Education : Manajemen Mutu Pendidikan. Yogyakarta: IRCiSoD.

Sani, dkk. (2018). Sistem Penjaminan Mutu Internal. Tangerang: Tira Smart.

Simarmata, J. (2015). Analisis Implementasi Penjaminan Mutu Di SMA Negeri 3 Kota Jambi. Jurnal Ilmiah Universitas Batanghari Jambi, 15(4), 54-62. 
Sudarsana, I. K. (2015). Peningkatan Mutu Pendidikan Luar Sekolah Dalam Upaya Pembangunan Sumber Daya Manusia. Jurnal Penjaminan Mutu, 1(Volume 1 Nomor 1 Pebruari 2015), 1-14. https://doi.org/10.25078/jpm.v1i1.34

Sugiyono. (2015). Metode Penelitian. Bandung: Alfabeta

Sulaiman, A., \& Wibowo, U. B. (2016). Implementasi Sistem Penjaminan Mutu Internal sebagai upaya Meningkatkan Mutu Pendidikan di Universitas Gadjah Mada. Akuntabilitas Manajemen Pendidikan, 4(1), 17-32.

Tius, R., Margareta, E., \& Ismanto, B. (2017). Strategi Perencanaan Pembiayaan Sekolah dalam Peningkatan Mutu di SMP Negeri. Manajemen Pendidikan, 4(2), 195-204.

Yakubu, U. S. L. and M. A. (2018). Quality Assurance Practice And Instructional Delivery Among Secondary School Civic Education Teachers In Kaduna State, Nigeria. British Journal of Education, 6(3), 41-56.

Rohmana, V. D., et al (2019). Evaluation of PJOK Learning In Sman I Karangan Trenggalek. Budapest International Research in Linguistics and Education Sciences (BirLE) Journal, 2(4); 642-647.

Rudi. (2019). Manfaat Rapor Mutu Hasil Pmp Bagi Sekolah.

Http://Vloggerpedia.Blogspot.Com/2019/10/Manfaat-Rapor-Mutu-Hasil

Pmp-Bagi.Html (Diakses Pada 5 November 2019 Pukul 10.10)

Peraturan Pemerintah Republik Indonesia No 13 Tahun 2015 Tentang

StandarNasional Pendidikan.

Peraturan Menteri Pendidikan Nasional No. 28 Tahun 2016 Tentang Sistem

Penjaminan Mutu Pendidikan Dasar dan Menengah.

Peraturan Menteri Pendidikan Nasional No. 26 Tahun 2008 Tentang Standar Tenaga Laboratorium Sekolah/Madrasah.

Peraturan Pemerintah No 19 Tahun 2017 Tentang Guru.

Undang -undang Sistem Pendidikan Nasional No 20 Tahun 2003. 